\title{
Claudel and Dante: Salvation on the Seventh Day
}

\author{
Ioana Sion \\ University of Toronto
}

$\mathbf{L}_{e}$ Repos du septième jour (The Rest on the Seventh Day), written in 1896, first published in 1901 in a collective volume of L'Arbre, illustrates the search for the cross, the passage from the centre of the world of the living, to the spiritual centre of God's realm. In the beginning, the Chinese Emperor" occupies "le centre et le milieu" (727) of his "Empire du Milieu" (729), and governs his world according to the universal rules of music. His role is to maintain the harmony between the visible and the invisible, to model the melody of the terrestrial world on the celestial one - on Dante's music of the spheres, "écoutant d'une oreille et de l'autre afin qu'aucune note ne se fausse" (787). However, the musical rules and the precepts of Antiquity are not enough to keep him connected to divinity, so he retires in solitude and contemplation in order to find the ultimate revelation.

In Le Repos the dead create havoc when they invade the world of the living, and the empire collapses as soon as the Emperor leaves the "sacred center". The intrusion of the dead is the result of an unknown sin. In order to restore harmony, the Emperor has to travel to the Underworld to find the cause and the remedy. His voyage, like Dante's, is also willed from above. The main three moments of the first act - leading to the Emperor's crossing into the other world - echo the three episodes of Christ's descent to Hell from the Gospel of Nicodemus and the analogous scenes from Dante's Inferno 8 and 9. The Emperor wears his body like a cross, and fulfills a Christ-like function. He aims at bringing the knowledge of salvation to his people and the revelation of the "centre". 


\section{Ioana Sion}

...Par la volonté du Ciel splendide,

Tout vivant et revêtu de la croix de mon corps, je suis descendu vers toi,

Pour te visiter dans ta loi et dans tes distributions,

Afin que rapportant au peuple des hommes et des animaux la paix,

Dissipant l'impieté de notre ignorance,

Je règne sur le royaume, dans la possession de la Connaissance et du Milieu! (747)

The second act presents his descent into Hell, which I will attempt to prove as Dantesque. Through edifying dialogues between the Emperor and the three guides: the Mother, the Demon and the Angel of the Empire, the root of evil is revealed. The remedy is suggested by the Angel: the laborer should first recognize God, then work six days and rest on the seventh, ${ }^{3}$ consecrating it to the Divine Creator. "Mais le septième jour qu'il se lave les mains et la tête, et qu'ayant mis un vêtement neuf, se tenant dans le repos, il célèbre la grande Attente" (770).

In his Dantesque search for the root of evil, the Emperor learns that the mystery lies in the way man perceives God. It seems that the dead cannot rest in peace, because the living have lost the right path to divinity. The third act reveals the passage from ruin to restoration: the Emperor returns from the Inferno in order to reestablish order and equilibrium among his people, peace and reconciliation between Heaven and Earth.

Odile Vetoë, in her thesis Claudel et Dante (1963), shows that the descent and exile of Dante, the poet-pilgrim, and Claudel, the poet-emperor started with the acknowledgement of their sinful life, and mentions the parallelism of their redemptive journeys. Briefly following the method of textual analysis developed by Patrice Pavis, Anne Ubersfeld, André Helbo in Théâtre: Modes d'Approche (1987), we can further identify categories such as space, time, objects, characters and actantial structures-Subject-Object, Helper-Blocker, Sender-Receiver-that foreground the similarities and oppositions to Dante in the overall structure or detail, and 
direct our attention to the relationship between the constitutive elements and the entirety of Claudel and Dante's representations of Hell.

At the beginning of his voyage, Dante the character abandoned the right path and lost himself in the selva oscura. At this point, his blockers are una lonza, un leone and una lupa (a leopard, a lion and a she-wolf). Claudel's Emperor is blocked by his assistants and the Nécromant, who at first takes him on the path of black magic. The Emperor (Subject), as the representative of a humanity distanced from God, starts his journey in order to redeem humanity's sin, to find the antidote for the evil invasion of the dead (Object). The motif of the descent (the trajectory of the subject's quest) is similar, as well as its goal, which is to seek peace and harmony, for the benefit of the world of sinners (Receiver). Dante's helpers are his guides, Virgil and Beatrice, who in the case of the Emperor correspond to the Demon and the Angel. The sender, indirectly, is God, while both Dante the pilgrim and the Emperor are privileged to be the recipients of a beatific vision and personal purification at the end of their journey. On their return they have acquired a new vocation, they are now prophets able to indicate the right path to others.

The archetype of Christ's descensus ad inferos is a common source for Dante's and Claudel's descents. The purpose of their descent is also similar, that is to find peace and harmony, to symbolically restore the unity of earth and sky, and to facilitate the communication between Man and God. Both writers are poets ${ }^{4}$ and theologians, they are shamans who attempt to unite all contrary principles, to realize the absolute unity in duality, the coincidentia oppositorum. This concept of totality is later used by Carl Jung to describe the ultimate aim of all psychic activity. It also informs the process of individuation, which essentially consists of a kind of coincidentia oppositorum, the union of the consciousness with the contents of the unconscious, accounting for the rose at the heart of the mandala, the mystic centre of the world. I will now further discuss in detail the three acts of the play. 


\subsection{First Act:}

\section{The Triple Descent of Christ, Dante and the Emperor}

The principal moments of the first act of Le Repos du septième jour can be juxtaposed with the three episodes of the Descensus Christi from the Gospel of Nicodemus ${ }^{5}$ and the corresponding scenes from Infermo 8 and 9 (Inf. VIII. 67-IX. 105), in an attempt to show how the plot, rhythm and style of the play recall that of the descensus. The history of salvation is the story of God's intrusion into human life, to liberate the people from death and decay (1 Cor. 15:54-56). To accomplish this redemptive mission, Christ comes into this world to release the captives and set free the oppressed (Luke 4:18). Dante's and Claudel's mandate is to show how God has liberated humanity from darkness and death, and led them into light.

\subsection{First Episode}

The first stage of the descent in The Gospel of Nicodemus is characterized by a resistance and a provocation arising from the forces of evil. Satan orders his infernal troops to prepare for the battle and he urges Hades: "prepare yourself to get him firmly into your power when he comes" (GN: Ch. 21).

Canto 8: 67-130 of the Inferno is marked by the same resistance and sfida of the countless number of demons: "io vidi piu di mille in su le porte..." (82). Virgil, "lo dolce padre," is invited to have a secret talk with them; the fallen angels, now demons, run back into the city, slamming the gates in Virgil's face, while Dante is seized by viltà. Virgil reminds us of the demons' insolence and their refusal to open the Gate of Hell upon Christ's arrival: "Questa lor tracotanza non è nova; / ché già l'usaro a men segreta porta, / la qual sanza serrame ancor si trova. / Sovr'essa vedestù la scritta morta..." (Inf. 8.124-7). The first Dantesque episode ends with the announcement of the expected visit of the messo celeste.

The first episode of Le Repos displays similar characteristics. The provocation caused by the forces of darkness occurs through 
the audacious sfida of the insolent dead, who invade and harass the living: "Mais ils errent la nuit dans les champs, ou sur les fleuves dans le brouillard, et comme des rats ils fourmillent dans les maisons [...]. Les froids se pressent autours de nous, et, silencieusement, ils assistent au repas, écoutant ce qu l'on dit, et quand la lampe est éteinte, ils nous touchent" (730).

\subsection{Second Episode}

In the second part of the Descensus Christi, a terrifying voice resonates three times: "Lift up your gates, ye princes; and be ye lifted up, ye everlasting gates; and the King of Glory shall come in!" (GN: Ch. 22). The forefathers having heard the voice, begin to castigate Hades, the "all-devouring and insatiable" and pressure him to open his gates. This second stage is dominated by the excruciating waiting for the arrival of Christ. All those swallowed up by Hades from the beginning of the world are disquieted, the demons are in turmoil.

Canto 9: 1-60 recounts the tormented waiting period before the arrival of the divine messenger. Dante asks whether anyone from the first circle has ever descended to that "sad hollow". We then learn that Virgil, while under the spell of Erichtho, a Thessalian witch, had previously descended to the circle of Judas to retrieve a damned soul (as described by Lucan in the sixth book of Pharsalia). Virgil is again powerless to deal with Medusa and appears to be deprived of confidence. The second act ends with the Furies, the handmaids of Persephone threatening the pilgrims with the appearance of Medusa's petrifying head. ${ }^{6}$

The Great Hoang-Ti, conjured up by the Nécromant through the power of the magic square, announces bluntly that the way to salvation can only be revealed by the one who follows Christ's descent and return from Hell. "L'Empereur: Qui donc nous expliquera le salut? / Hoang-Ti: Lui-même, celui qui descendent chez les morts on est revenu" (741). This second moment is also marked by the anguished waiting for the arrival of Christ's follower. The Prime Minister, The Great Examiner and the First Prince and 


\section{Ioana Sion}

their assistants anxiously await the Saviour or the messo celeste. "Quels recours invoquerons-nous? vers quels dieux joindrons-nous les mains?" (743). The Emperor then takes the decision to follow Christ, Aeneas and Dante's example and cross the threshold of the Underworld while alive. In the style of the Gospel of Nicodemus, the Emperor addresses the Inferno directly: "je demanderai à l'Enfer même son grief" (743). The First Prince even uses the word "gate" when questioning his father: "Franchirez-vous la Porte tout vivant?" (743). Imitating Christ's thundering voice, which resonates three times while asking the Inferno to open up, the Emperor, empowered by his "Bâton Impérial", also urges three times the earth to let him in: "Ouvre-toi, ô Terre! Ouvre-toi! ô Terre!" (745); "Ouvre-toi, fais-moi passage!" (745); "Ouvre-toi, livre-moi passage!" (746).

\subsection{Third Episode}

In the final act of this sacra rappresentazione, Christ appears, the gates of brass are broken into pieces, the bars of iron are crushed and the dead freed from their chains. "And the King of Glory entered in like a man, and all the dark places of Hades were illuminated" (GN: Ch. 22). Christ triumphantly enters into the house of darkness, capturing and imprisoning his archenemy Lucifer. ${ }^{7}$ He gives him to Hades who banishes him into his depths. Subsequently Christ liberates Adam and the holy fathers from Hell: "What was lost through the tree of knowledge was redeemed through the tree of the cross." 8 When they arrive in Paradise, they are welcome by Enoch and Elijah, also by the good thief carrying his cross on his back.

Canto 9: 64-105 completes the sacra rappresentazione, which is an imitation of Christ's gesture: only through Christ's action can the interdiction of the Sybil be cancelled, only divine intervention can defeat Satan. The arrival of the messo celeste is the most significant moment of this final episode. He performs the much-awaited miracle of opening the gates of the civitas diaboli 
with his wand, his verghetta. ${ }^{9}$ The City of Dis then opens its iron gates and grants free passage to Dante and Virgil.

The Emperor, who substitutes himself for the messo celeste and proceeds as Christ's imitator, uses his "Bâton Imperial" instead of the messenger's verghetta. The earth quakes and opens up. The Emperor starts his descent in act 2. He does not fight or imprison Satan, but, even without facing him, snatches his secret of the absolute, which will bring him closer to the divine presence. Deciphering the enigma of the Anti-Christ, "le Saint de l'Enfer", will help understand the path to Heaven. Like Dante, the Emperor does not attempt to save the dead, but the living. Like the good thief who was saved, the Emperor shows himself carrying the cross at the Gate of Paradise and Hell: "Je reparais à la porte fatale! Sur le seuil qui est entre la Mort et la Vie, je me tiens debout avec le signe de la Croix". (774). Upon his return, he reveals the path to Paradise to his people, who, like Beckett's tramps wait for salvation in the ante-chamber of the Inferno: "sacré vestibule! temple du monde où l'homme erre, comme un prêtre frappé d'oubli" (777). The Emperor, similarly to Dante's divine messenger appears as a post-figuration of Christ and his actions, as demonstrated, can be interpreted according to the typology of the descensus.

Christ's harrowing unlocks both Hell's and Heaven's Gates, making it possible for man to enter Paradise. The Sabbath or rest on the seventh day provides the key to experience God's redemption and is inextricably linked to the harrowing. Both celebrate the victory of Christ over Satan, of light over darkness, of good over evil. Christ's victory reverses the tragedy of the fall, the descensus marks the triumphant conclusion to the drama of the redemption, and through synecdoche it stands for redemption and human liberation from physical, psychological and metaphorical bondage.

\subsection{Second Act: The Infernal Voyage}

The Inferno discovered by the Emperor in the second act of Repos du septième jour resembles that of Dante in all four dimen- 


\section{Ioana Sion}

sions of space and time, as well as in architecture. Time has lost its meaning: "Le temps n'est plus!" (746) and the "ténèbres irrémédiables" (749) have obliterated the light. Claudel appropriates the terms "enceinte": "Et voici la seconde enceinte où le Feu fait connaître sa vertu" (755) and "cercle": "Ce premier cercle de Feu est appelé l'Ébullition" (756), and generally follows the structure of the Dantesque Hell divided in circles and ruled by Satan. We can identify the Antechamber, the Lower and Upper Hell. However, the subdivisions are blurred, and there is no trace of the "bolge". Claudel's usage of the "cercle" and "enceinte" is a very eloquent tribute to Dante, as the two words seem otherwise improper in this Underworld devoid of physical barriers. His inferno is an immaterial, boundless space. It is defined and becomes undoubtedly Dantesque through the description of the character's sins and ways of punishment.

Claudel's first circle is that of ignorance: the Mother is lost in the absolute darkness, "plus noir que la noirceur" (746). The eternal blindness could be approximated to that of the AnteInferno, the vestibule of the Neutrals with "blind vision". It is a realm of "sighs, lamentations and loud cries" (Inf. III.22): "gémissements", "sanglots" and "cris" (747). In Le Repos we find the souls of those who never did anything right or wrong, and never knew true light. The Mother confesses: "Aveugle je suis allée au lieu aveugle, et mon séjour est l'aveuglement" (750). Although no apparent crime was committed-"Je n'ai commis aucun crime!"her docility and neutrality have brought her damnation. Because she refused to see the true light, she is now condemned to eternal darkness.

Claudel's second circle is that of anger and incontinence. The violent are "cooking" in the black fire while they attack each other. They are mixed with the avaricious, the gluttonous devastated by perpetual hunger "les gourmands ont faim" (760), and the envious drained by thirst and crying with tears of vinegar: "Les envieux désséchés ont soif et versent des larmes de vinaigre" (760), the proud and the fornicators. Claudel's treatment of envy is highly original, and doesn't seem to have any connection to Dante's, in 
Purgatory. The avaricious keep their fingernails stuck into their palms: "Les avares étrangles; / Serrés à la gorge par l'esquinancie, les ongles enfoncés dans les paumes, les dents entrées les unes dans les autres, / Ils se tordent, ne pouvant expulser de leur ventre l'oeuf d'or" (755). The image of the clenched fist is also the symbol used by Dante to describe his avaricious characters. They are first shown pushing weights in circles, with their chests, for eternity "voltando pesi per forza di poppa" (Inf. VII. 27). The tight fist is associated later with the avaricious: "Questi resurgeranno del sepulcro / col pugno chiuso..." (Inf. VII. 56-7).

Most correspondence is to be found in the handling of the carnal sinners:

Les fornicateurs sont joints les uns aux autres, mêlés ensemble comme des cadavres qui mollissent, comme le suif qui fond et colle,

Par deux, par trois,

Par dix, par trente, en grappes tel qu'un farcin de crapaud,

Ils culbutent dans la nuit qui bout, dissout dans un spasme atroce. (760)

This imagery recalls the "hellish hurricane" of Dante's second circle, that of the Lustful, punished for the sins of the flesh: "La bufera infernal que mai non resta, / mena li spiriti con la sua rapina: voltando e percotendo li molesta" (Inf. V. 31-3). Like Francesca and Paolo, "quei due che'nsieme vanno" (Inf. V. 74), Claudel's fornicators will never be parted from each other. Similarly to Claudel's interpretation, Francesca designates her lover: "Questo, che mai da me non fia diviso" (Inf. V. 135).

In Dante's five circles of Upper-Hell are punished the sins of incontinence. Dante's pagans (corresponding to the mother) followed by the Lustful, Gluttonous, Avaricious, Prodigal, Wrathful and Sullen, correspond closely to Claudel's sinners of the second circle. Claudel's third circle is that of the anti-scientists, disciples of matter, joined to the rock, juncti petrae: "Entassés et repliés sur 


\section{Ioana Sion}

eux-mêmes ils cuisent", permeated by the icy fire and the frozen light they sought. They correspond to the inhabitants of Dante's Lower-Hell, who have been punished for their malice, especially the Heretics and the Epicureans of the sixth circle; Dante's other three circles of Lower Hell, those of the Violent, the Fraudulent and the Treacherous, are less discernable in the drama.

Pride seems to be the worst sin, in Claudel's system, as well as in Dante's. The proud do not have their own circle in the Inferno, but Dante gives us a thorough description of the supreme specimen - Satan, in the ninth circle. The giant emperor of the dark kingdom of pain is half buried in the ice of Cocytus, in the centre of the earth: "Lo'mperador del doloroso regno / Da mezzo il petto uscia fuor de la ghiaccia..." (Inf. XXXIV, 28-9). As commentators have noted, the crucifixion of Lucifer at the bottom of Hell is a sarcastic reference to Christ's cross, just as the three faces of Satan are an oblique, inverted reference to the Holy Trinity. Pride has a special place in Claudel's Hell, the supreme refuse of God is unique. He refers to all his sinners in the plural, only the "orgueilleux" is alone, fixed in eternal solitude, like Dante's Satan, the principal of all evil and embodiment of pride par exellence. The proud shadow described by Claudel is stuck into the ground in an isolated crucifixion:

Mais l'orgueilleux rigide est fiché tout seul dans la terre comme un pal; l'aveuglement et la solitude éternelle sont sa part;

Ses genoux sont retournés, ses articulations font noeud;

Et, ou bien, écarté comme une croix, il supporte la lourdeur de ses bras,

Ou en silence il travaille à relever sa tête sur la vertèbre cassée.

Mais la plante des pieds vit et une pointe subtile la ronge et la dissèque. (760)

According to Reboul, the last verse recalls the punishment of the Simonists in Inferno XIX. They are stuck head down in 
equally sized holes cut into the rock of the eighth circle, third pouch, feet up, their soles consumed by fire. Dante's fire can thus be compared with Claudel's "pointe subtile", which also accounts for the "peine du Dam", along with the physical torture. At its essence, fire is God's fundamental principle.

Mais pourquoi employer ces vaines images, quand le Feu suffit à tout expliquer?

Car de même qu'en vous la souffrance avec exactitude découvre et suit la lésion du nerf le plus délié,

C'est ainsi que le Damné est examiné par le Feu indéfectible. (760)

For Claudel, as for Dante, the Inferno is part of the divine design. Espiau de La Maëstre notes in his article on Satan that: "l'Enfer éternel fait partie intégrante du programme transcendent divin, de l'équilibre providentiel, historique et apocalyptique" (8). Odile Vetoë in her thesis on Claudel and Dante also underlines: "Claudel présente un Dieu qui a besoin de tout l'univers pour son plan de salut: des êtres et des choses, du bien et du mal. C'est le Dieu contenant de toutes choses de Dante: de l'enfer - du mal aussi bien que du paradis" (309). Claudel doesn't give us more specific details of the torments of Hell, since the essence of the infernal punishment is the same as that of divine redemption: the fire that illuminates or tortures. The same fire nourishes the saints and burns the sinners, the emperor is told by the Demon. The method of damnation is the one of salvation, which is love. Hellish fire is at the antipode of divine light, but at the same time they constitute a fundamental coincidentia oppositorum.

Et c'est ce qui est écrit dans les livres: "un même feu brûle dans une triple demeure." Ce même feu qui nourrit en vous la vie

Dans le Ciel est des êtres bienheureux la splendeur et la fusion

Qui de l'Enfer est la passion et la brûlure. (757) 


\section{Ioana Sion}

\subsection{Third Act: Final Rest and Redemption}

Following his descent into Hell, the Emperor brings to his people the cross, the symbol of resurrection to the eternal life, of sublime intersection, the true centre of conversion:

...je tiens entre mes mains le signe royal et salutaire!

Voici la sublime intersection en qui le ciel est joint à la terre par l'homme.

Voici le jugement entre la droite et la gauche, la séparation du haut et du bas. Voici l'oblation et le sacrifice!

Voici le très saint Milieu, le centre d'où s'écartent également les quatre lignes, voici l'ineffable point. (774)

The drama ends with the triumph of one of the main symbols of Claudelian and Heideggerian thought: the fourfold or the quaternity, which designates the ontological totality of the world. It constitutes the essence of being, the experiential space of existence. In his essay "Bauen, wohnnen, denken" (1954), Heidegger describes this oneness of the four in which earth and sky, divinities and mortals belong together. According to Heidegger, it is simple dwelling or presence of nature and being under the sky that guards the fourfold. "In saving the earth, in receiving the sky, in awaiting the divinities, in initiating mortals, dwelling occurs as the fourfold preservation of the fourfold" (53). Claudel's empire can be saved by finding and preserving the fourfold, by bringing God into dwelling. Claudel's cross - when at the centre of being - brings salvation and guards the mortals' dwelling on earth.

At the end of his drama, Claudel creates a sacred place of meditation and mediation between earth and sky in the "Grande Montagne" (784), where only the initiated in search for the invariable truth are accepted. This is where the New Emperor, "L'Empereur nouveau" (788) finds refuge at the end of his voyage. His son, left in the contingent world, inherits his glorious role of being the milieu of the world of the living: "Prends ma place avec toute puissance, assume avec magnificence le Milieu!" (782). The 
former Emperor now becomes the mediator between the sacred and the profane, a crosser of boundaries, a psychopomp. In him the two realms coincide. He is the archetype of self and of wholeness, the coincidentia oppositorum of the universal being and the individual "I". Immersed in God, the Emperor is now the sphere whose centre is everywhere and whose circumference is nowhere. According to Venanzio Amoroso, he is "le Médiateur par excellence" and at the same time "l'Homme Universel" (103). Through ecstatic contemplation, the interpreter of the invisible realm can listen to the primordial sound and receive the divine emanation. "Dessus, devant, derrière, à droite, à gauche, dessous, / Tu est partout, et cependant tu n'as ni haut ni bas, / ni mesure ni étendue, ni apparence. / Je suis devant le Vide!" (786). The final encounter with Divinity seems elusive and cannot be described, it can only be experienced. On the verge of wholeness, there is always the danger of the void. "Contemplation of God's being and God's oneness elevates the perceptive soul into the heights of mystical paradox and divine wonder... God is at once perceived by the grace-filled soul, and still beyond the grasp of the limited mind" (Talbot 25). Like Dante and Saint Bonaventure, Claudel does not admit a direct vision of divine Truth, even in the final mystical union between Man and God. God is unknowable, invisible, and transcendent as well as immanent. As Dante puts it, "O luce etterna che sola in te sidi, / sola t'intendi, e da te intelletta / e intendente te ami e arridi!" (Par. XXXIII, 124-6)..$^{10}$ Like Christ, placed at the centre of intersection between two worlds and having a double nature, the Emperor's transient presence becomes one with the immanent essence, mediating between the human and the divine. On the seventh day, penetrated by the fire of the Holy Spirit, the Son passes over into the Father in a transport of contemplation (Bonaventure 38). And so, the New Emperor ascends from the depths of Hell to the top of the Mountain of Purgatory, and into the Divine sphere.

The rest on the seventh day marks the end of Creation, which is also the beginning of the Universe as we imagine it. It is a sacred milieu of contemplation, which can be symbolized by the 


\section{Ioana Sion}

hermeneutic circle of understanding and interpretation. The Sabbath is attained in the act of reading the Rest on the Seventh Day. The act of reading becomes an act of contemplation and the play takes the reader to the point of sublime rest. The critical tradition established by Erich Auerbach and Charles Singleton asserts that the Comedy must be taken to be literally and therefore historically true. Wiliam Franke argues that the most significant implications of the poem's claim to truth and historicity concern not the literal and historical senses of the narrative so much as the existential historicity of the reader. The locus of the making of history, and the discovery of the true nature of the Self is not the plot of the poem or drama so much as the act of reading. All the descents are concerned with saving souls: Virgil descended so that one soul might be saved from the pain of the ninth circle (Inf. IX). Christ descended to save a host of souls from the torments of Hell (Inf. IV). Dante descended to learn the path to God and show it to the reader. The Christian reader of Dante's poem or of Claudel's play may also be counted among those who will be saved from Hell. Salvation can be attained through the act of reading or witnessing the play, which takes the reader/spectator through the journey of descent and ascent.

\subsection{Conclusions. Homo Claudelianus and Wholeness}

In this paper on Le Repos du septième jour I have discussed the fable, the actantial structures, space and temporality, objects and characters, and Dantesque intertextuality. The Inferno discovered by the Emperor distinctly resembles that of Dante. The infernal punishments seem to emerge in the same order: darkness, fire, ice. Claudel even uses the terms "enceinte" and "cercle" (literal appropriations), and follows the structure of the Dantesque Hell (structural appropriations of space). The division in three acts echoes the three canticles, and each act has three main episodes. ${ }^{11}$ Most similarities are to be found in the handling of the sins of the flesh, as we have already noted. The fornicators of the second cir- 
cle are relentlessly molested by the bufera infernal - the spasme atroce of Claudel's drama, which appears to be the result of a spiritual punishment, the fundamental "peine du Dam".

The Claudelian Inferno centred in Satan presents itself as a parallel and opposing universe to heaven, with its centre in God. The mother in the first circle even names it "le ciel d'en bas" (748). Both the celestial and the infernal universes are formed by a series of concentric circles obeying the centre. The first circle or circumference farthest from Satan is the limbo, ${ }^{12}$ which contains the blind neutrals and ignorants, immersed in darkness and passivity. The second circle of desire comprises the sins of the emotions, where the lustful, gluttonous, wrathful, etc. are chaotically moving between the centre and the periphery, in a disordered, excruciating vibration. The third circle with its central black sun is that of Anti-science where the sinners of the intellect are punished by being joined to the rock in total stillness. The Satanical centre is an inverse image of the Godhead, the void opposing the plenitude of being, the nothingness as counterpart to wholeness. It is called the black sun and the paradise of hate: "soleil noir", "Paradis de la Haine" (763). Lucifer is the black God or the infernal saint: "Dieu noir" (740), "Saint de l'Enfer" (763). The Emperor is associated with the moon, he is "pareille à la lumiere de la Lune" (728), and the centre of the terrestrial empire, while God is the sun at the centre of the celestial kingdom. He is "le Roi des Vivants", while Satan is "l'Empereur des Morts" (731). The element of fire is the link uniting the two universes, ${ }^{13}$ the principle of divine retribution, the "Feu divin" becoming "Feu pénal". in Hell (756).

The difference rests in the author's sentiments towards his sinful characters: Claudel's coldness opposes Dante's pity and sympathy. Claudel is too great a poet to closely imitate Dante, but, argues Yves Reboul, the many "coincidences" that bring together the two texts are more than just reminiscences, and Claudel's drama is in fact "une véritable transposition" of the master's text in modern clothing. Although we cannot speak of a master-disciple relationship, according to Odile Vetoë, we can definitely argue that the Divine Comedy is a perpetual object of meditation and 


\section{Ioana Sion}

inspiration for Claudel, as the poet confesses in his unpublished letter to Louis Gillet from June 25 $5^{\text {th }}$ 1941: "Mais c'est une de ces oeuvres dont le souvenir ne s'efface pas et qui, une fois accueillie, continuent en nous une espèce de travail latent, elles restent en état de permanence, de référence continuelle, de réponse diverse aux questions que notre propre cours vient leur proposer." 14

According to Zoel Saulnier and Eugene Roberto (25), Claudel aims at a syncretism between the Chinese and Christian orientations, the Taoist beliefs and the Christian tradition. The hierarchy of the Y-King is comparable to that of the Genesis. Gilbert Gadoffre demonstrates that the drama is set in a conventional China, a "Chine de convention", as L'Annonce faite à Marie takes place in a "Moyen Age de convention" (256); the only authentically Chinese component is the aggressive omnipresence of the dead. In essence, "l'Enfer moral et méthaphysique du Repos du septième jour appartient à l'univers judéo-chrétien et à lui seul" (257).

The spherical self of Claudel's Emperor, as of all living beings, is created and delineated by an undulating energy that emanates from the centre and whose final wave forms the circumference. The search for the innermost, ideal self is realized through a circular, cyclical descent and ascent. It is the Emperor-Poet who initiates and creates his journey, but it is also the journey that defines the traveler. As Enrico Garzilli puts it, echoing Carl Jung: "The journey and the pilgrim, the dream and the dreamer become one as man explores a circle whose circumference seems to be everywhere and whose centre seems to be nowhere. This circle is himself' (Garzilli 8).

The ultimate salvation comes from the two intersecting diameters forming the cross, which unites the circumference to the centre. As in the case of the Dantesque self, the symbolism of the cross inscribed in a circle is associated with the individuation of the Claudelian self. The squaring of the circle, Carl Jung's archetype of wholeness, is what Claudel's Emperor seeks, as well as Dante's pilgrim. Finally, "tout vient se mesurer à ce double 
diamètre d'un cercle invisible qui discerne le droit et le gauche et le haut et le bas" (EM 192). Time is like a turning space, believes Claudel, and the double diameter anchors and gives the real measure and genuine coordinates of the self. The circle or the zero, true image of the finite as of the infinite - when combined with the cross - grants the supreme harmonic roundness to the self.

Claudel's work, as well as Dante's, reveals a gigantic effort to reunite two worlds, to re-establish the wholeness of the universe and of man. The two poets tenaciously attempt to find the way back to the center, reinstate order and peace and achieve "centering" through a mythic descent to Hell. They seek to abolish the separation between the unconscious and the conscious mind, and achieve individuation through the integration of the invisible into the visible. The recognition and investigation of Hell will show the way to redemption and wholeness of being. Yet another modern mandala play within a Dantesque frame, Claudel's drama of metaphysical exile and homecoming brings along spiritual regeneration while performing a cyclical ritual of inner descent and ascent to the central point of being.

\section{Bibliography}

Amoroso, Venanzio. Paul Claudel et la recherche de la totalité. Paris: Honoré Champion Éditeur, 1994.

Bonaventure, Saint. The Journey of the Mind into God. Itinerarium Mentis ad Deum. Indianapolis: Hackett Publishing Company, 1993.

Brodeur, Léo. Le Corps-sphère. Clef de la symbolique claudélienne. Montréal: Cosmos, 1970.

Brunel, Pierre. L'Évocation des morts et la descente aux enfers. HomèreVirgile-Dante-Claudel. Paris: Société d'Édition d'Enseignement Supérieur, 1974.

Bugliani, Ann. The Instruction of Philosophy and Psychoanalysis by Tragedy. Jacques Lacan and Gabriel Marcel Read Paul Claudel. San Francisco: International Scholars Publications, 1999. 


\section{Ioana Sion}

Cattaui, Georges. "Dante et Claudel". Bulletin de la société d'études dantesques du centre universitaire méditerranéen, no. 17-18, 1968-9. 3-8.

Chiari, Joseph. "Theology and Love in Claudel." The Poetic Drama of Paul Claudel. New York: Gordian Press, 1969. 129-38.

Claudel, Paul. Correspondance, 1899-1926. Paul Claudel et André Gide. Préf. et notes par Robert Mallet. Paris: Gallimard, 1949.

. Correspondance, 1907-1914. Jacques Rivière et Paul Claudel. Paris: Plon, 1946.

. "Introduction à un poème sur Dante." Positions et propositions (PP). Paris: Gallimard, 1938. 11-186.

. Le Repos du septième jour. Théâtre I. Paris: Gallimard, 1947. 725 790.

- L'Épée et le miroir (EM). Paris: Gallimard, 1939.

. Mémoires improvisés (MI). Jean Amrouche, ed. Paris: Gallimard, 1954.

. Oeuvre Poétique (OP). Paris: Gallimard, 1957.

Daniel, Yvan. Paul Claudel et L'Empire du Milieu. Paris: Les Indes Savantes, 2003. 123-66. 265-322. 361-400.

Espiau de la Maëstre, André. "Satan dans l'oeuvre théâtrale de Paul Claudel." Claudel Studies, vol. XIII, no. 2, 1986. 4-21.

- Paul Claudel bibliste et ses prophètes. Paris: Les Belles Lettres, 1993.

Dante Aligheri. Inferno. Transl. Allen Mandelbaum. New York, Toronto: Bantam Books, 1984.

Festa, Bianca Maria. Motivi di ispirazione dantesca in un poeta moderno: Paul Claudel. Milano: Gastaldi Editore, 1960.

Freccero, John. The Poetics of Conversion. Cambridge: Harvard University Press, 1986.

Gadoffre, Gilbert. "Claudel et l'Univers chinois." Cahiers Paul Claudel 8. Mayenne: Gallimard, 1968. 255-63.

Garzilli, Enrico. Circles Without Centre: Paths to the Discovery and Creation of Self in Modern Literature. Cambridge: Harvard University Press, 1972. 


\section{Claudel and Dante: Salvation on the Seventh Day}

Gilson, Etienne. "Claudel, poète chrétien". Nouvelles littéraires 19, 1968. 6-18.

Gounelle, Rémi and Zbigniew Izydorczyk, Transl and Introd. Evangile de Nicodème. Turnhout, Belgium: Brepols, 1997.

Heidegger, Martin. "Building, Dwelling, Thinking." Poetry, Language, Thought. New York: Harper Colophon Books, 1971.

Houriez, Jacques. Le Repos du septième jour. Paris: Les Belles Lettres, 1987. Hulme, William Henry. The Middle English Harrowing of Hell and Gospel of Nicodemus. London, New York, Toronto: Oxford UP, 1961.

Iannucci, Amilcare. "The Gospel of Nicodemus in Medieval Italian Literature: A Preliminary Assessment." The Medieval Gospel of Nicodemus. Texts, Intertexts, and Contexts in Western Europe. Ed. Zbigniew Izydorczyk. Tempe: Medieval and Renaissance Texts and Studies, 1997.

Malicet, Michel. Lecture psychanalytique de l'oeuvre de Claudel. I $\mathcal{E}$ II. Paris: Les Belles Lettres, 1979. Vol I: Les Structures du théatre de Claudel. 18-20. 115-20. 209-11. Vol II: Le Monde imaginaire de Claudel. 20-7.

Millet-Gérard, Dominique. "Chapitre IX. Claudel poète-théologien: la référence dantesque." La Prose transfigurée. Vingt études en hommage à Paul Claudel pour le cinquantenaire de sa mort. Paris: Presses de l'Université Paris Sorbonne PUPS, 2005. 219-39.

Musa, Mark. "At the Gates of Dis." Advent at the Gates: Dante's Comedy. Bloomington and London: Indiana UP, 1974.

Ouvrard, Pierre. "Le Mystère de la Rédemption: Le Repos du septième jour." Aux Sources de Paul Claudel. Litterature et foi. Laval: Siloë, 1994. 134-44.

Paliyenko, Adrianna M. "Revealing Divine Order." Misreading the Creative Impulse. The Poetic Subject in Rimbaud and Claudel, Restaged. Carbondale: Southern Illinois UP, 1997. 111-32.

Petit, Jacques, Ed. Paul Claudel 10. L'Enfer selon Claudel. Le Repos du septième jour. Paris: Lettres modernes Minard, 1973.

. Paul Claudel 1. Quelques influences formatrices: Eschyle, Virgile, Dante. Lettres Modernes no. 101, 1997. 


\section{Ioana Sion}

Poulet, Georges. "Chapitre XVII. Claudel". Les Métamorphoses du cercle.

Paris: Plon, 1961. 477-99. English translation. The Metamorphoses of the Circle. Baltimore: Johns Hopkins Press, 1967. 321-35.

Reboul, Yves. "Dante et Claudel: Les damnés du Le Repos du septième jour." Revue de littérature comparée, no. 44, 1970. 73-81.

Rigolot, C.N. "The Symbol of the Circle and the Centre in the Works of Claudel." Claudel Studies, vol. I, no. 2, 1973. 47-57.

Saulnier, Zoël et Eugène Roberto. Le Repos du septième jour. Sources et orientations. Ottawa: Éditions de l'Université d'Ottawa, 1973.

Spitzer, Leo. "Le style 'circulaire". Modern Language Notes, no. 55, November 1940. 495-499.

Talbot, John Michael. The Lover and the Beloved. A Way of Franciscan Prayer. New York: Crossroad Publishing, 1985.

Van de Ghinste, Josée. "Chapitre VIII. Le Repos du septième jour." La recherche de la justice dans le théâtre de Paul Claudel. Paris: Nizet, 1980. 103-16.

Vetoë, Odile. "Claudel et Dante". Rerue des Lettres Modernes. Claudel 1, No. 101-103. Paris: Minard, 1964. 67-98.

- Claudel et Dante. Thèse de doctorat. Bibliothèque de la Sorbonne, 1963.

Vickers, Nancy J. "Claudel's delectation in Dante." Claudel Studies, vol. VIII, no. 1, 1981. 28-41.

Viscusi, Anthony. "Order and Passion in Claudel and Dante." French Review 30, 1957. 442-50.

Wilhelm, Julius. "Paul Claudel und Dante". Zeitschrift für französische Sprache und Literatur. Heft Mai 1969. 32-48.

\section{Notes}

1 Some of his titles are: Fils du Ciel, Premier, Unique, le Un, Fondation, Principe, Milieu (727). The Prime Minister praises the Emperor: "tu règles l'harmonie par qui le Ciel est joint à la terre" and 
"tu gouvernes avec sagesse selon les règles de la Musique et le précepte de l'Antiquité" (728).

2 Claudel's fascination with the mysterious centre of the circle is well known. One of his favourite themes is the infinite zero, "le cercle qui est le type de toutes formes, fini et cependant infini, oeuf, semence, bouche ouverte, zéro" (Paul Claudel et André Gide, Correspondance, 91). He considered the circle to be a totality, the archetype of all forms and coinciding principles. He envisioned humankind displayed in the shape of a circle around a common centre, according to Georges Poulet and C.N. Rigolot, in the image of a vast mandala or wheel of life. Being projects itself in concentric circles like waves starting from a "point unique" until the final fulfillment: "L'être... remplit continuellement ce territoire circulaire... par une vibration qui va du centre à la périphérie" (MI 195). "L'être rond" has a concentric organisation and its development and universal expansion is always circular and cyclical and always limited by a of circumference. "Tout être vivant est un cercle plus ou moins modifié, mais toujours limité par un contour" (Correspondance avec Jacques Rivière, 61). Every being is a variation of the circle or sphere. Miguel Serrano, in a letter to Carl Jung defines the Self as a circle or centre of being, which carries man to the limit of existence and into the essence, where he is both creator and created. "In a way, that mysterious centre is our son, but at the same time it is our father. The Son who is the Father, the Self" (Serrano 83). In the milieu, Man tends to coincide with God, existence with essence, the circle becomes the centre. Creation can never escape revolving in circles around the divine centre, God has to be followed like the circle obeys its centre, "Il faut obéir comme le cercle au centre" (OP 14), the whole universe is attracted toward this central reality situated at the point of intersection of the two diametres that form the circle and the cross.

3 The divine rest can be regarded as the moment taken by God to behold his creation. This contemplative glance is mainly focussed on man and entails aesthetic pleasure, generated by the beauty of what was accomplished (according for instance to Jean-Paul II's Dies Domini). God sanctified this seventh day by a special blessing, and 


\section{Ioana Sion}

made it his day par excellence. In all Romance languages, the name for Sunday reflects the name of God, Dominus: domenica, duminica, dimanche, domingo; in Portuguese, o domingo is the first day of the week, since Monday is the second- a segunda-feira etc., again underlining the fact that the end is in the beginning, God's day is the centre of the week and also the moment when the circle of time starts and is complete. Man enters in dialogue with God during the spiritual rest on the seventh day, devoted to prayer and praise of the Creator. To stop daily work is to break the paralysis of everyday life, to extract the self from the contingent and devote oneself to absolute and essence.

The seventh day is the only day of the Genesis, which did not have an evening. The godly rest has neither morning nor evening, since it has neither beginning nor end. A symbol of the circle of eternity, the Sabbath makes visible the pact with the Creator, by marking the recognition of God's love, the dialogue of God and Man, visible and invisible, divine and profane. As Claudel tells us, the Divine Comedy like his own work is a token of the final union of humanity and divinity: "La Divine Comédie se résume finalement dans la rencontre de Dante et de Béatrice, dans l'effort réciproque de deux âmes séparées par la mort [...] c'est cette rencontre essentielle que j'ai essayé à mon tour, après beaucoup d'autres lecteurs, d'imaginer et de peindre, c'est ce dialogue de deux âmes et de deux mondes..." $(P P, 181)$.

4 The name for poet in the Latin world was that of prophet, vates.

5 For a detailed discussion of the descent motif, see Amilcare Iannucci's "The Gospel of Nicodemus in Medieval Italian Literature: A Preliminary Assessment." The Medieval Gospel of Nicodemus. Texts, Intertexts, and Contexts in Western Europe. Ed. Zbigniew Izydorczyk. Tempe: Medieval and Renaissance Texts and Studies, 1997.

6 Dante borrows his account of Medusa's ability to petrify from Ovid: Metamorphoses 4. 793-803.

7 "Then the King of Glory seized the chief ruler Satan by the head and handed him over to the angels, saying: Bind with iron fetters his hands and his feet and his neck and his mouth" (GN: Ch. 22). 
8 Hades tells Satan: "All that thou hast gained through the tree of knowledge, all hast thou lost through the tree of the cross: and all thy joy has been turned into grief; and wishing to put to death the King of glory, thou hast put thyself to death." Gospel of Nicodemus. Chapter 23.

9 Benvenuto da Imola and Pietro di Dante assimilate the verghetta with the caduceus of the god Mercury. They further identify Mercury with Eloquence and the angel of mediation.

10 "Eternal Light, You only dwell within / Yourself, and only You know You; Self-knowing / Self-known, you love and smile upon Yourself!" (Par. XXXIII, 124-6).

11 Act 1: The descensus has three moments; Act 2: The Emperor travels along three rings of Hell escorted by three guides; Act 3: The return of the Emperor; his public appearance; his retirement on the mountain.

12 Limbo etymologically means the periphery of a circle.

13 An insightful and concise image of the Claudelian universe is given by Josée van de Ghinste in the following: "La structure de l'Univers claudélien semble maintenant fort précise: c'est celle d'un immense disque dont l'endroit représente l'Univers du Bien, formé d'enceintes concentriques autour d'un Centre/Dieu (Être, Soleil, etc.) et dont l'envers représente l'Univers du Mal, formé de façon symmétrique d'enceintes concentriques autour d'un Centre/Satan (Néant, Lucifer, soleil noir, etc.). Les deux Centres sont face à face comme deux adversaires, et le moyeu qui traverse cette roue est le glaive de la Justice, ce feu qui extase dans l'Univers du Bien, et le feu pénal dans l'Univers du Mal" (116).

14 Paul Claudel. "Lettre inédite à Louis Gillet". 25 June 1941. Quoted by Odile Vetoë in her unpublished doctoral thesis Dante et Claudel. Bibliothèque de la Sorbonne, 1963. 10. 